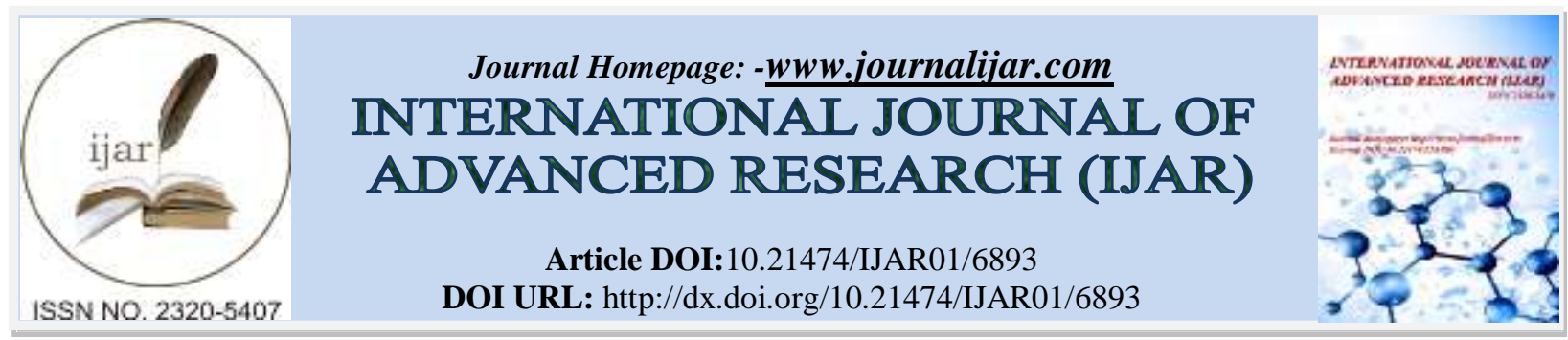

RESEARCH ARTICLE

\title{
HYDRO-GEOCHEMICAL EVALUATION OF GROUNDWATER AND AQUIFER CHARACTERISTICS- A CASE STUDY FROM SADAR UPAZILA OF CHAPAINAWABGANJ DISTRICT, BANGLADESH
}

Mohammad Alamgir Kabir ${ }^{1}$, Md. Kamal Hossain ${ }^{2}$, Faruk Hossain ${ }^{1}$ and Mohammad Omer Faruk Khan ${ }^{1}$.

1. Assistant Director, Geological Survey of Bangladesh.

2. Deputy Director, Geological Survey of Bangladesh.

\section{Manuscript Info}

Manuscript History

Received: 09 February 2018

Final Accepted: 11 March 2018

Published: April 2018

Keywords:-

Groundwater, Contamination, Quality Assessment, Barind Tract, Floodplain,

Public Health, Trace Element, Arsenic

\begin{abstract}
Concern over the effects of different chemical elements in groundwater quality and negative impact on human health is growing with the growth of population both in rural and urban areas. With this view, a hydro-geochemical investigation has been carried out in Sadar Upazila of Capainawabganj District. Through this research work, attempts have been made to identify water bearing zones, assessment of water quality, mineralogical composition of sediments. The study area is characterized by two different geomorphologies namely the Barind Tract and Flood Plain areas. In the investigated areas, two water bearing zones have been detected within the depth of 50 meter; one is in the Flood Plain area and the other is in the Barind Tract area. Groundwater is more or less acidic to neutral in both the areas while oxidizing environment is present in the Barind Tract area and reducing environment is in the Flood Plain area. The chemical analysis of groundwater sample reflects that the major elements are calcium $(\mathrm{Ca})$, sodium $(\mathrm{Na})$, magnesium $(\mathrm{Mg})$, chloride $(\mathrm{Cl})$, sulfate $\left(\mathrm{SO}_{4}\right)$, bicarbonate $\left(\mathrm{HCO}_{3}\right)$ and the minor elements are potassium $(\mathrm{K})$, iron $(\mathrm{Fe})$, nitrate $\left(\mathrm{NO}_{3}\right)$, nitrite $\left(\mathrm{NO}_{2}\right)$, phosphate $\left(\mathrm{PO}_{4}\right)$ and fluoride $(\mathrm{F})$. The trace elements are cobalt $(\mathrm{Co})$, copper $(\mathrm{Cu})$, manganese $(\mathrm{Mn})$, nickel $(\mathrm{Ni})$, zinc $(\mathrm{Zn})$, arsenic $(\mathrm{As})$, lead $(\mathrm{Pb})$ and cadmium $(\mathrm{Cd})$. In groundwater, the concentration of most of the elements are within the limit of DoE standard except $\mathrm{Mn}, \mathrm{Ca}, \mathrm{Mg}, \mathrm{HCO}_{3}$ and $\mathrm{F}$. Minerals like quartz, feldspar, mica, hornblende, chlorite, illite, montmorillonite etc are identified in the sediment samples. The above elements and minerals are playing important roles in terms of groundwater quality. As long as the equilibrium condition of subsurface geochemical environment remains uninterrupted there is less possibility of any significant change in water quality. Thus one has to be careful before taking any water supply scheme.
\end{abstract}

Copy Right, IJAR, 2018,. All rights reserved.

\section{Introduction:-}

Groundwater is considered as one of the most important natural resources throughout the world. In Bangladesh, groundwater plays a vital role as a source of drinking water both in urban and rural areas. Till 1997, it has been claimed that $97 \%$ population depend on groundwater as safe source of drinking water and $70 \%$ of irrigation 
coverage comes from ground water (BGS-DPHE, 2001). Most municipal water supplies are also dependent on groundwater. Moreover, detection of arsenic (As) has decreased the dependency on potable use to 79\%. During field survey, it has been noticed that the people of Sadar Upazila of Chapai Nawabganj District are using groundwater mostly for drinking and irrigation purposes. High concertation's of dissolved As in tube well water was first reported in West Bengal Province of India back in 1978 (Goriar et al., 1984; Guha Mazumder et al., 1988; Acharyya et al., 1999). Arsenic is reported to occur in the shallow to medium aquifer of the country as documented by laboratory analysis of well waters (BGS and DPHE, 2001) and field testing. It is not a local issue. Many researchers reported natural geological sources for high concentrations of As $(>10 \mu \mathrm{g} / \mathrm{l})$ in groundwater for many parts of the world such as Bangladesh, India, Nepal, Pakistan, China, Myanmar, Cambodia, Vietnam, Taiwan, Iran, Mongolia, United States of America (Bhattacharya et al., 1997; 2002a, 2006, Welch et al., 2000; Manadal \& Suzuki, 2002; Nickson et al., 2005; Garciaet al., 2006; Berg et al., 2007; O’Shea et al., 2007; Mukherjee et at., 2008a). However, it is one of the arsenic prone upazilas of Bangladesh where presence of elevated concentration of arsenic was first detected in 1993 by the Department of Public Health and Engineering (DPHE). In addition to arsenic, many other elements in groundwater may give rise to undesirable or toxic condition through a deficiency or an excess depending on certain characteristics of subsurface geo-environment, groundwater flow and residence time as well as bed rock nature. Geomorphology, hydrogeology and depositional history also play a significant role on groundwater quality. There is a growing concern about the groundwater quality as it is directly linked to human health and has an impact on food chain. However, hydro-geochemical investigations so far being carried out in this upazila is insignificant. Thus, due to the concern over the effects of such factors in groundwater use, a hydro-geochemical investigation has been carried in this upazila with a view to unveil the number of water bearing zones in relation to geological formations, mineralogical composition of sediments of water bearing zone, chemical composition of ground water along with existing subsurface environment within the depth of 50 meter.

\section{The Study Area:-}

The study area is the Sadar Upazila of Chapi Nawabganj District which is located in the north-western part of Bangladesh. The area lies between the latitude $24^{\circ} 25^{\prime}$ and $24^{\circ} 42^{\prime} \mathrm{E}$ and the longitude $88^{\circ} 06^{\prime}$ and $88^{\circ} 26^{\prime} \mathrm{N}$ covering an area of $451.08 \mathrm{sq} \mathrm{km}$ (Figure 1). It is bounded by Nachole and Shibganj upazilas on the north, West Bengal of India on the south, Tanore and Godagari on the east and Shibganj Upazila on the West. Physiographically the study area is characterized by the Old Mahananda flood plains \& Young Ganges flood plains in the south-west portion and the elevated Barind Tract in the north-east portion. The Old Mahananda flood plain is characterized by broad, nearly level ridge within broad basins. High, broad flat land and numerous small and big Beels comprise this flood plain. The high land is not flooded during the monsoon but the low-lying areas are low to moderately flooded. Tectonically the investigated area lies within the Chapai Nawabganj- Gaibanda Intracratonic High (Khan and Rahman, 1992). It is bounded by a major north-south trending fault which forms the boundary between the Mahananda River in the west and Barind Tract in the east. Structural and tectonic information of the region reveals that the Barind Tract occurs as a horst block along preexisting, well defined line of crustal weakness with compensatory subsidence of the bordering regions like Mahananda flood plain. The upliftment of the Barind Tract up to its present elevation has resulted from the reactivation of the transverse faults across the Intracratonic (Khan and Satar, 1994). 


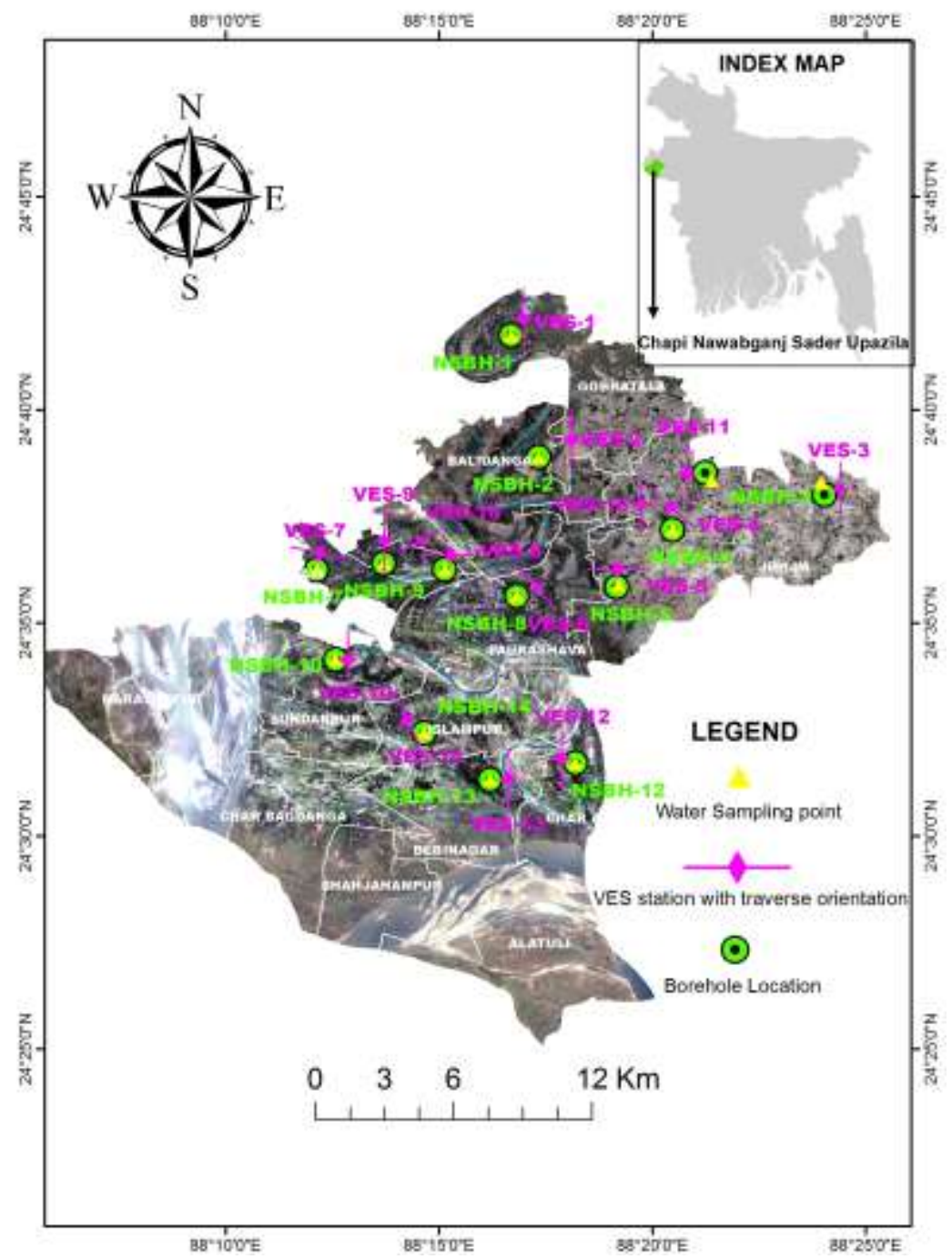

Figure 1:-Location map of the investigated area with boreholes, water sampling and VES points.

The straight-edge escarpment of the river Mahananda signifies the existence of a major fault in the region (Khandoker, 1987). The Young Ganges flood plains comprises mainly of moderate high land and small beels (depression) with moderate hazard of river bank erosion. The area is drained by the Mahananda, the Padma, the Mora Padma and the Pagla rivers. The weather is dry \& cool during the periods of November to February and becomes very hot during March to May. Monsoon starts in June and continues till September. The minimum and maximum temperature varies between $9^{\circ} \mathrm{C}$ and $41^{\circ} \mathrm{C}$. The rainfall is generally low and average annual rainfall is in the range of $1447 \mathrm{~mm}$. Maximum rainfall occurs during the months of June to September. Wind condition generally is light throughout the year but strong wind blows for short period in pre-monsoon often in association with thunderstorms and occasionally with hail (Source: BBS: 2012).

\section{Materials And Methodology:-}

The hydro-geochemical investigation has been carried out in two phases. The first phase consists of primary datacollection on physiochemical parameters of groundwater followed by collection of water samples from tube wells and sediment samples from boreholes and geophysical data of boreholes as well. The second phase consists of chemical analysis of groundwater samples and mineralogical identification of both clay and granular minerals of sediments in the laboratory. A total number of 14 boreholes were drilled by chopping method maintaining distance between individual boreholes is approximately $6 \mathrm{~km}$. Borelogs data were recorded for each borehole during the drilling time for the cross section. Ground water level data were recorded in all the boreholes. A total No. of 51 sediment samples was collected from water bearing zones. Out of 51 samples 18 are clay samples and 33 are sand 
samples. The clay samples were analyzed through X-RD(Panalytical XPERT-PRO, Generator Setting 30mA 40kV, $\mathrm{Cu}$ Tube) and sand samples have been studied under polarizing microscope in the Petrology and Mineralogy Lab of the Geological Survey of Bangladesh (GSB).The base map of the study area was collected from LGED; Dhaka. Groundwater sampling was done from Shallow Hand Tube Wells (STW), Irrigation Wells (IW) and TARA Hand Pump situated within the periphery of the boreholes. GARMIN 12 channel GPS was used to record the geographic location of the sampling points. Two High Density Polyethylene sample bottles of $500 \mathrm{ml}$ were used for groundwater sampling. In the laboratory, each of the sample bottles have been conditioned with $20 \% \mathrm{HNO}_{3}$ and in the field, prior to sample collection each bottles have been rinsed three times with de-ionized water to minimize potential elemental contamination and again rinsed with water sample immediately before samples being collected. In all cases, $0.45 \mu \mathrm{m}$ membrane filter was used to filter groundwater samples in order to remove colloidal materials and unwanted particles from the water samples. Filling up two $500 \mathrm{ml}$ bottles with groundwater sample and acidifying one with conc. $\mathrm{HNO}_{3}$ and another with conc. $\mathrm{HCl}$ to bring down the pHvalue below 3 in order to avoid precipitation of the dissolved constituents from the samples. Relevant site informations including details of the location, type of the pump depth etc. were recorded in a data sheet during sampling. Field parameters such as $\mathrm{pH}$, Dissolve Oxygen (DO), Oxidation Reduction Potential (ORP) and Temperature were measured under flowing condition using flow through cell and were recorded for each sample on the spot using Ion Selective Meter. At the same time, Total Dissolve Solid (TDS), Electrical Conductivity (EC), Salinity, Turbidity, Resistivity and arsenic concentration have also been measured and recorded. Cation concentrations have been measured by using Atomic Absorption Spectrometry (AAS-VGA). $\mathrm{Na}^{+}$and $\mathrm{K}^{+}$have been measured by flame analyzer (Glanchamp). Anion concentrations have been measured by using Ion Chromatography in the laboratory of analytical chemistry branch of GSB. In order to cross-check the borehole lithologs and to locate the water bearing zones of the study area two geophysical techniques namely Geophysical Logging and Resistivity Survey (Vertical Electrical Sounding, VES) have been adopted. These data were processed by using numbers of software's to represent them with diagrams. Various contour maps were produced by using Arc GIS 10 and Rock Works $2006^{\circledR}$ was used to show hydrostratigraphic cross sections and models. Microsoft Excel was used for preparation of data sheet. A comprehensive location map of the various data collection points has been given in Figure 2.

\section{Results and Discussion:- \\ Hydrogeology:-}

Aquifer configuration of the study area:-

The study area is covered by alluvial sand of the Ganges and the Mahananda flood plain deposits in the south and central parts and alluvial silt and clay in the northern part. The main sources of subsurface information are the 14 borehole logs that have been carried out in different locations of the study area. The depth of the boreholes ranges from $27.40 \mathrm{~m}$ to $46.60 \mathrm{~m}$. The regional stratigraphic succession of the area has been documented by Khan and Mominullah (1980) as a thick sequence of sediment ranging from Cretaceous to Recent overlying Archean basement. According to Mansur (1995) the Quaternary deposits exposed in the area can be subdivided into two broad units i) Barind Clay and Sand Formation represented by deep reddish-brown, highly oxidized and weathered clay, silty clay and sand at the bottom and ii) Rohanpur Silty Clay Formation represented by yellowish grey silty clay to clay with organic matter and plant roots at the top. Holocene water bearing formation covers most of the study area in the north-western, south-western and south-eastern portions 


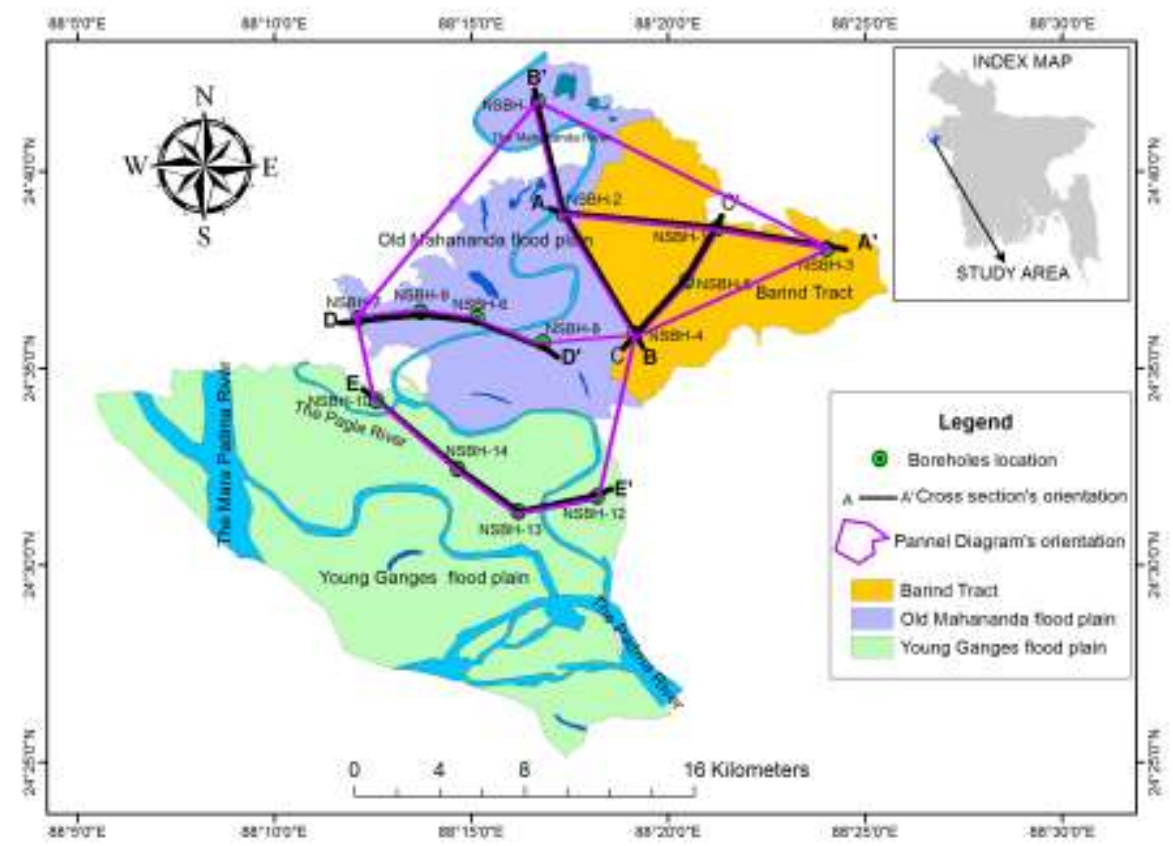

Figure 2:-Map showing the orientation of the hydro-stratigraphic panel diagram and cross-sections.

while Plio-Pleistocene (Dupi Tila) water bearing formation only belongs to north-eastern part of study area. A very few systematic hydro-geochemical surveys have been conducted in the study area. A hydro-stratigraphic panel diagram of the study area based on 14 borelogs have been constructed by using Rock Works $2006^{\circledR}$ computer application. Finally, a generalized hydro-stratigraphic model has been proposed for the study area. The layout of the panel diagram and the cross sections are shown in Figure 2.

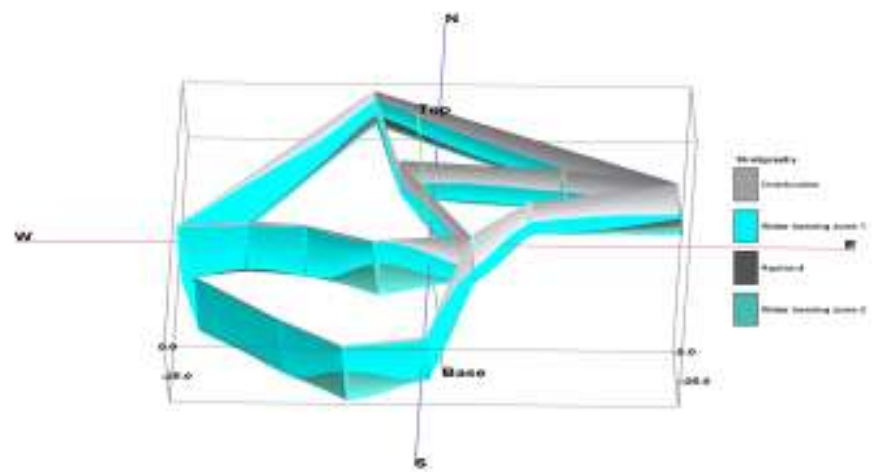

Figure 3:- Hydro-stratigraphic panel diagram.

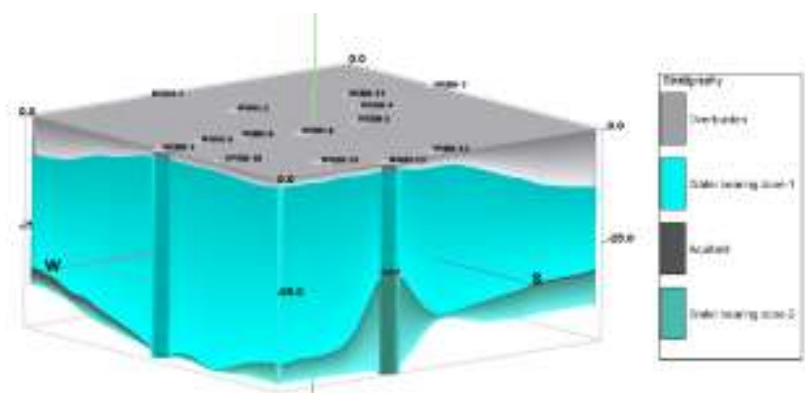

Figure 4:- Hydro-stratigraphic Model (south-west view) 


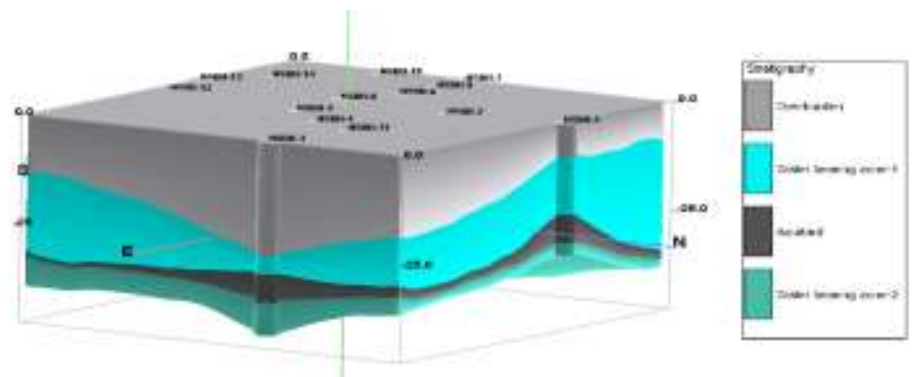

Figure 5:- Hydro-stratigraphic model (north-east view).

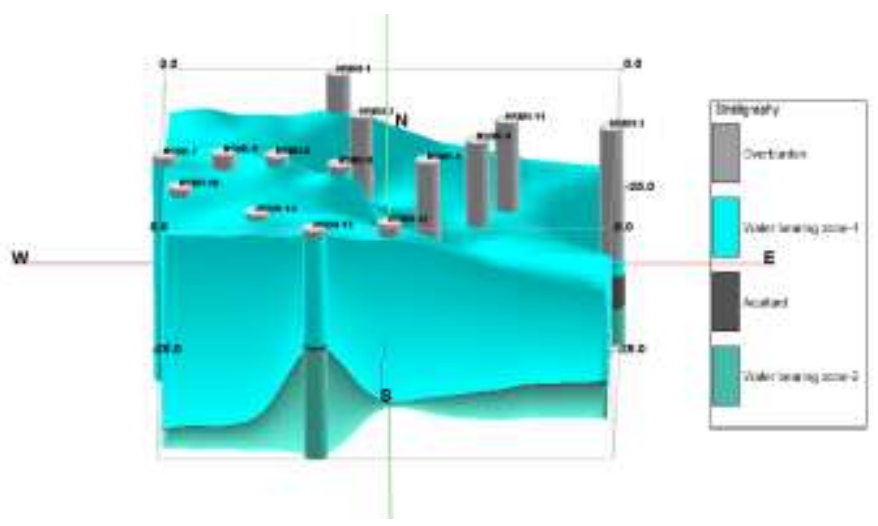

Figure 6:- Hydro-stratigraphic model (Water bearing Zone-1).

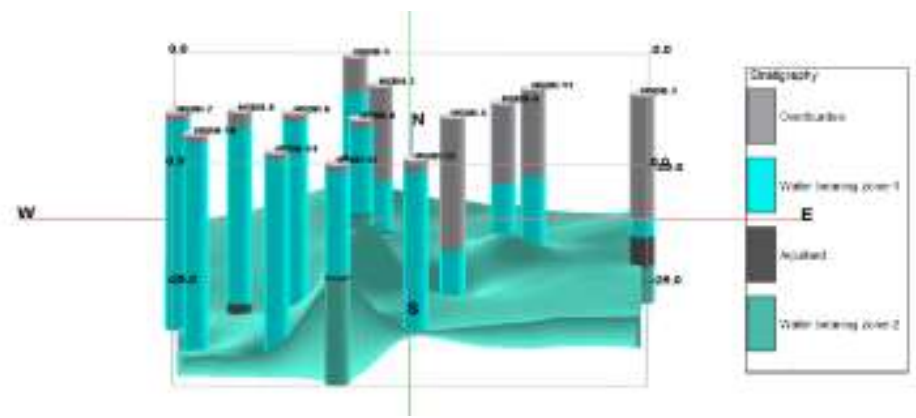

Figure 7:- Hydro-stratigraphic model (Water bearing Zone-2).

From the panel diagram (Figure 3) it is evident that there are considerable variations in the aquifer configurations of the study area both in north-south and east-west directions. The study area can be vertically sub-divided into two water bearing zones, Zone-1 and Zone-2 up to the depth of $50 \mathrm{~m}$, based on the presence of discontinuous clay layer having a thickness of $1 \mathrm{~m}$ in the western and southern portions (Figure 4) to more than 5 meters in northern and eastern portions (Figure 5) of the study area. The Zone-1 (Figure 6) is comparatively thin $(5 \mathrm{~m})$ in north-eastern part of the study area but it is getting thicker $(15 \mathrm{~m})$ in the south and western direction. The Zone-2 (Figure 7) is more variable in thickness within the depth of $50 \mathrm{~m}$. Since its base could not be identified; the thickness could also not be identifiable. But the top is encountered at the depth of $25 \mathrm{~m}$ in the middle portion of the study area in north-south direction and gradually increases in depth up to $45 \mathrm{~m}$ toward south-western direction.

The Dupi Tila formation is not exposed in the study area but acts as the main water bearing zone in the northern part. The formation is mainly sandy and consists of medium to coarse ferruginous sands. On the other hand, the main water bearing zone in the south and central parts is the Holocene floodplain deposit. Five hydrostratigraphic cross-sections have been constructed based on borehole lithologs. Cross sections are being made along AA', BB', $\mathrm{CC}^{\prime}, \mathrm{DD}$ ' and EE' lines. The sections show that there is a significant variation in the aquifer geometry of the study area. From the surface expression, the study area can be horizontally divided into Young Ganges zone, Old 
Mahananda zone and Barind Tract zone. Based on lithology, stratigraphy and depositional history zone wise detailed description is given below.

\section{Barind Tract Zone:-}

In this Zone, both the water bearing zones (Zone-1 and Zone-2) belongs to Plio-Pleistocene (Dupi Tila) formation. This zone consists mainly of well oxidized yellowish to brownish yellow, fine to coarse grained sand. In the cross section along line AA' the maximum thickness of Zone- 1 is $15 \mathrm{~m}$ in the western part particularly at Balidanga Union and minimum thickness is $5 \mathrm{~m}$ in the eastern part particularly at Jhilim Union (Figure 8). In the cross section along line BB', Zone-1 is more or less consistent in thickness which is about $15 \mathrm{~m}$ (Figure 9) tending to slope toward west. Since, all the boreholes along the cross section CC' (Figure 10) are within the Zone-1, the thickness of this zone could not be identified along this section. Water bearing Zone-2 may be more vertically extended. Therefore, the thickness of this zone could not be attained. The water bearing zone is confined due to the presence of impermeable and thick overburden clay deposit above the water bearing formation.

\section{Old Mahananda Zone:-}

In this zone, the water bearing formations (Zone-1 and Zone-2) belong to Holocene. They consist mainly of recent fine to coarse grained channel fill deposits of the Mahananda River. In the cross section along line DD', the maximum thickness of Zone- 1 is $45 \mathrm{~m}$ in the west at Ranihati Union and minimum thickness is $20 \mathrm{~m}$ in the east at Pourashova (Figure 11). The Zone-2 may be more vertically extended. Therefore, the thickness of this zone could not be attained. The presence of semi-permeable overburden deposit consisting of silty clay above the water bearing formation renders its nature to be semi-confined to unconfined.

\section{Young Ganges Zone:-}

In this zone, ground water abstracted from both the water bearing zones belongs to Holocene water bearing formation, consisting mainly of recent, fine to coarse grained channel fill deposit of the Pagla, the Mara Padma and the Padma rivers. The maximum thickness of Zone-1 is more than $47 \mathrm{~m}$ and minimum thickness is $25 \mathrm{~m}$ at Debinagar Union as shown in the cross section along line EE' (Figure 12). The Zone-2 may be more vertically extended. Therefore, the thickness of this zone could not be availed. The presence of thin semi-permeable overburden deposit consisting of silty clay above the water bearing formation confirms the unconfined in nature of water bearing formation.

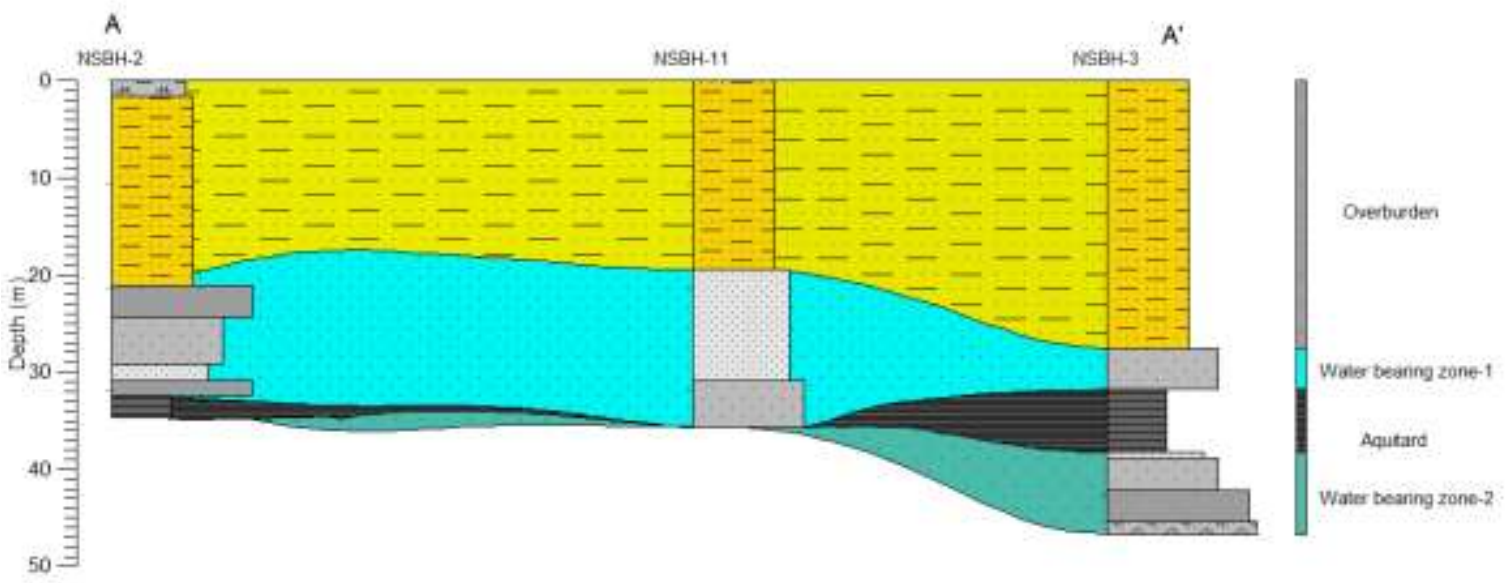

Figure 8:-Hydro-stratigraphic cross-section along line AA'. 


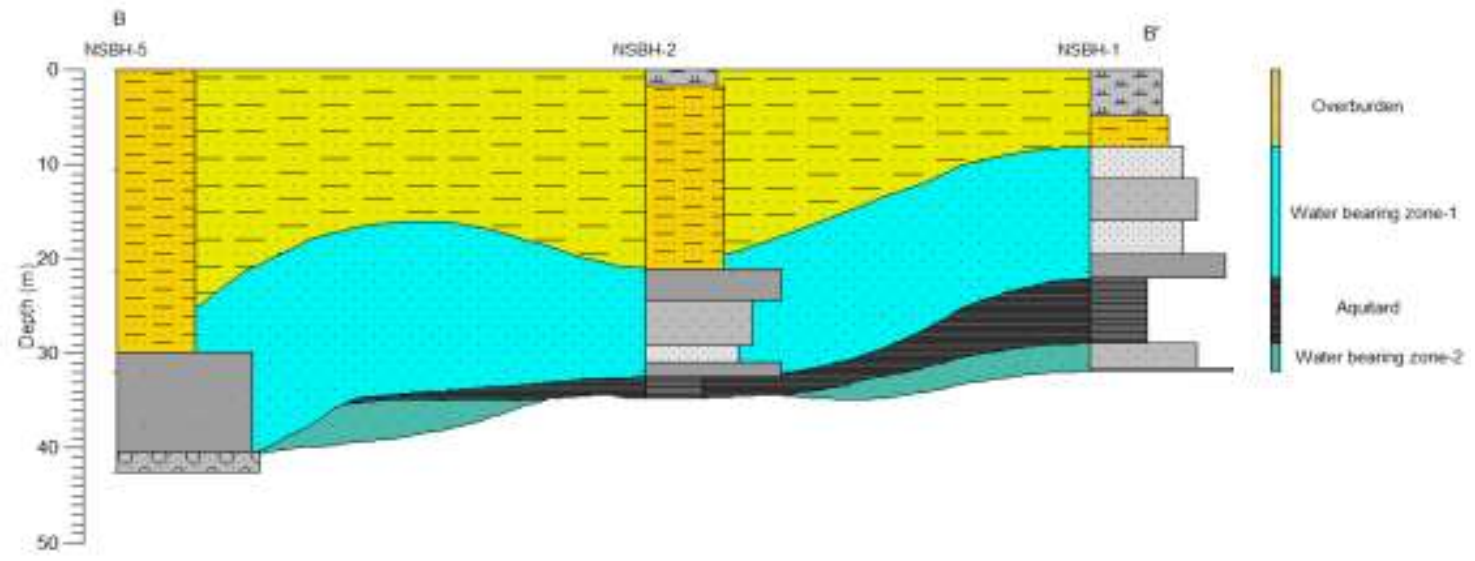

Figure 9:- Hydrostratigraphic cross-section along line BB'.

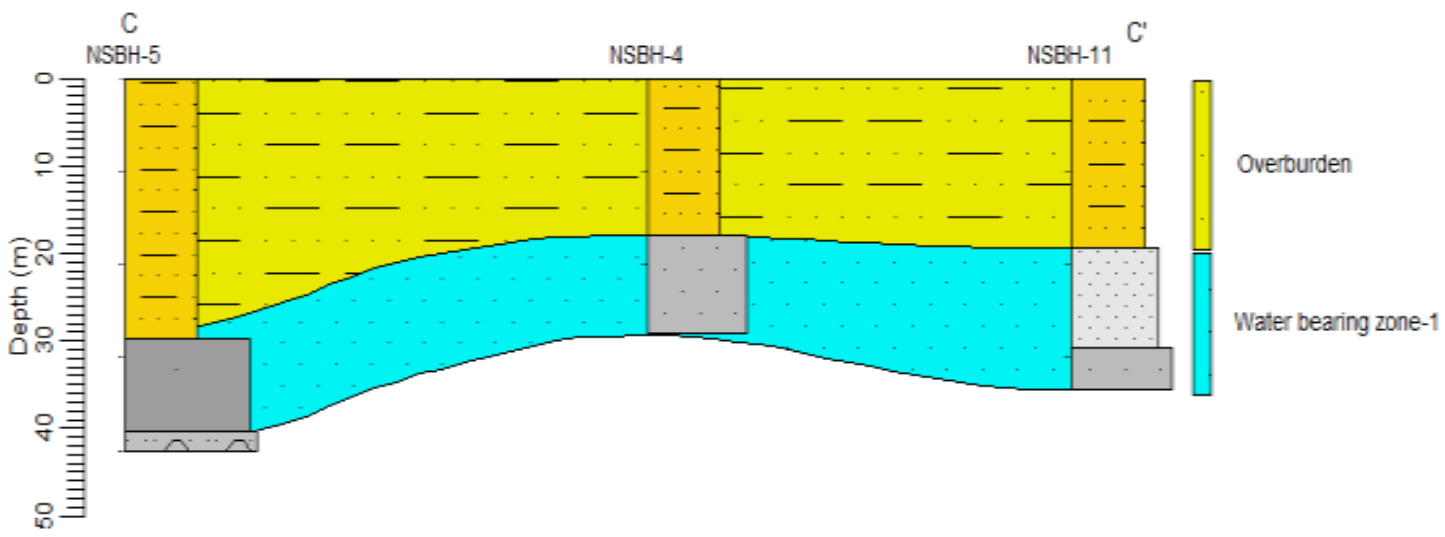

Figure 10:-Hydro-stratigraphic cross-section along line CC'.

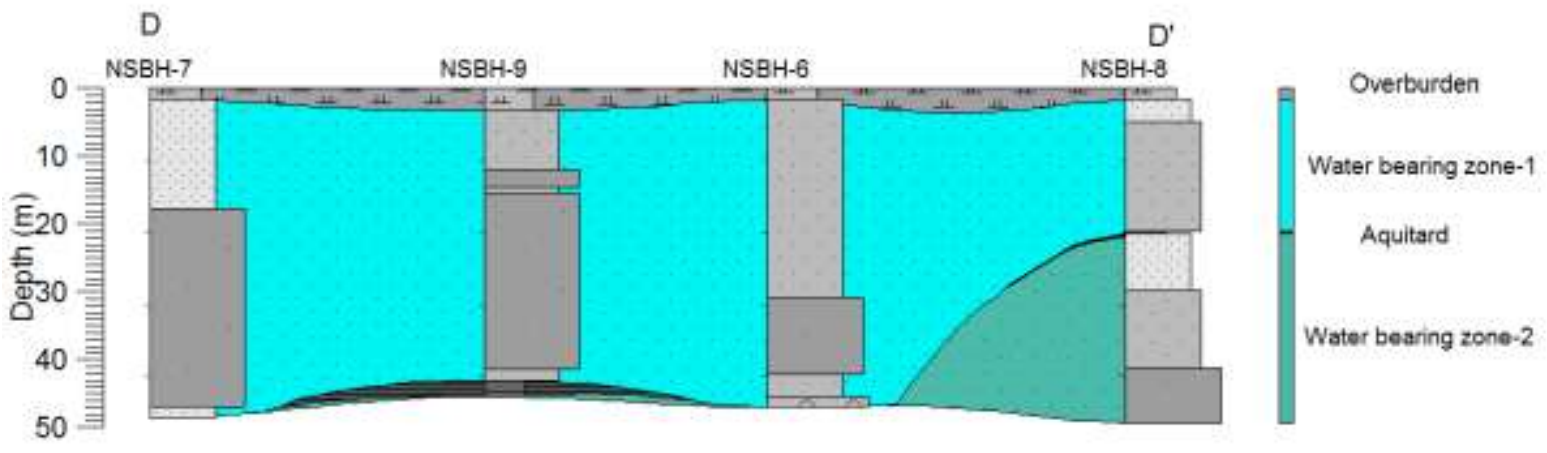

Figure 11:-Hydro-stratigraphic cross-section along line DD'. 


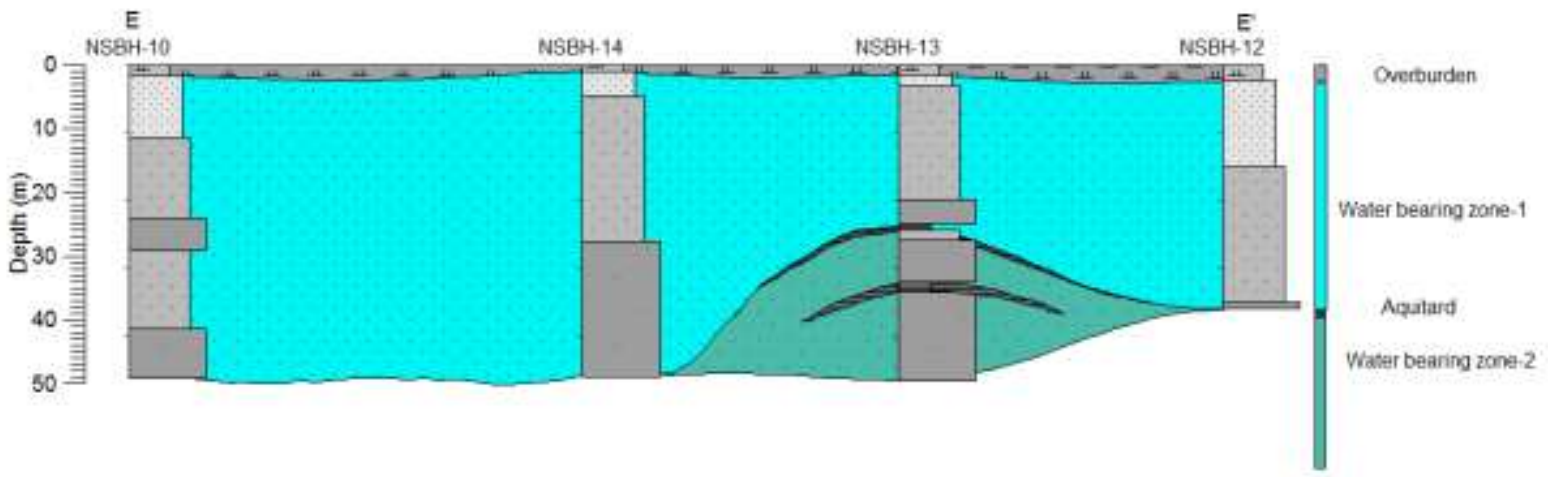

Figure 12:- Hydro-stratigraphic cross-section along line EE'.

\section{Groundwater Table Elevation and Flow Pattern:-}

The groundwater levels data measured from 14 representative tube wells in the study area have been used to prepare water table elevation contour maps to observe water table fluctuations during the field survey in the month from February to March (dry season). Considering the study area to be situated $25 \mathrm{~m}$ above mean sea level (MSL) groundwater table elevation contour map is prepared (Figure 13). Three stages of water table elevation have been observed during dry season in three distinct geomorphic units. In Barind Tract unit water table elevation is within the range of $10-13 \mathrm{~m}$, in the Old Mahananda Floodplain it is $15-17 \mathrm{~m}$ and in the Young Ganges Floodplain it is 17$19 \mathrm{~m}$. The local groundwater flow pattern within these geomorphic units is radial as there is presence of some distinct peaks. The maximum water table elevation is $19.6 \mathrm{~m}$, found at Char Anupnagar village in Char Anupnagar Union in the Young Ganges Floodplain geomorphic unit and minimum is $10 \mathrm{~m}$, found at Sisatola Village in Jhilim Union in the Barind Tract geomorphic unit. From the contour maps it is observed that the water table elevation in the Barind Tract (north-eastern part) is lower than the other parts of the study area. Therefore, the general groundwater flow is to north-east from south-west.

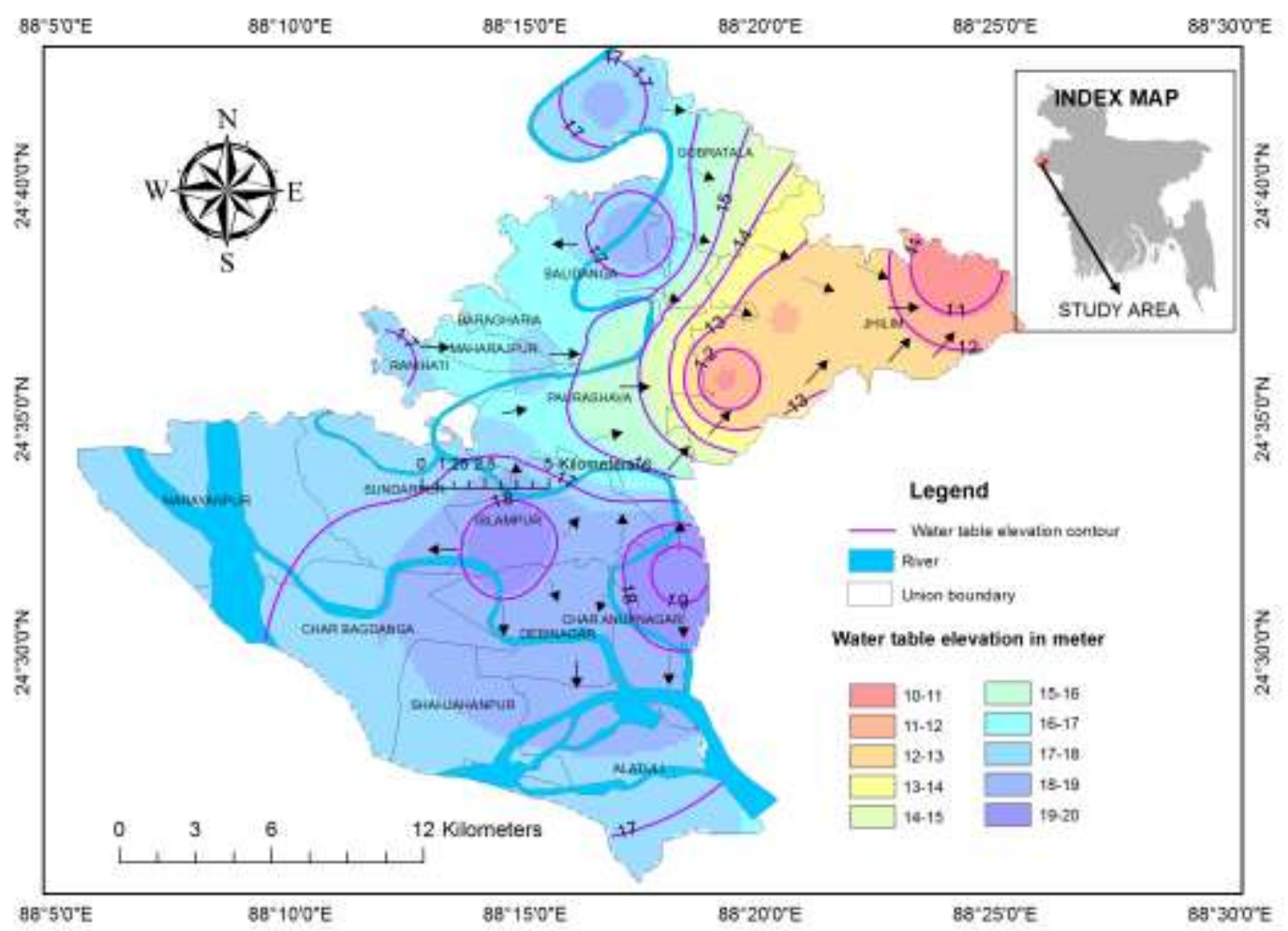

Figure 13:-Water table elevation contour map showing groundwater flow direction. 


\section{Groundwater Chemistry:-}

Groundwater chemistry deals with the concentration of chemical elements in groundwater which is related to the soluble products of rocks and minerals weathering and decomposition and changes with respect to travel and residence time (Raghunath, 1990) and interaction with different solute.

\section{Physicochemical parameters:-}

The $\mathrm{pH}$ value of the groundwater of the study area ranges from 6.31 to 7.17. It indicates the groundwater condition of the study area is acidic to neutral. Out of 14 ground water samples, three samples are below the DoE (Department of Environment) standard limit and other 11 samples are within the standard limit. Maximum pH value of 7.17 has been recorded at a STW $(24.39 \mathrm{~m})$ located at Char Anupnagar Union and minimum pH value of 6.31 has been recorded at a STW $(49.01 \mathrm{~m})$ located at Jhilim Union. The study area is characterized mostly by low EC values $(<1000 \mu \mathrm{S} / \mathrm{cm})$ but in some areas relatively high EC values have also been recorded. Maximum value of $1048 \mu \mathrm{S} / \mathrm{cm}$ has been recorded at a STW $(13.72 \mathrm{~m})$ located at Maharajpur Union and minimum value of $500 \mu \mathrm{S} / \mathrm{cm}$ has been recorded at a STW $(36.59 \mathrm{~m})$ located at Jhilim Union. TDS values for all the 14 ground water samples are within the DoE standard limit. Maximum value of $517 \mathrm{mg} / \mathrm{l}$ has been recorded at a STW $(13.72 \mathrm{~m})$ located at Maharajpur Union and minimum value of 6.31 has been recorded at a STW $(36.59 \mathrm{~m})$ located at Jhilim Union. DO value ranges from 0.07 to $5.06 \mathrm{mg} / \mathrm{l}$. Most of the DO values are less than $1 \mathrm{mg} / \mathrm{l}$. All the recorded DO values are within the DoE standard. Maximum DO value of 5.06mg/l has been recorded at a STW $(49.09 \mathrm{~m})$ located at Jhilim Union and minimum value of $0.07 \mathrm{mg} / \mathrm{l}$ has been recorded at a STW $(21.34 \mathrm{~m})$ located at Islampur Union of the investigated upazila. The measured ORP values in the Barind Tract area are positive and in the flood plain areas are negative indicating that the hydrogeochemical condition of the water bearing formation in the Barind area is oxidizing and in the flood plain area is reducing. ORP values range from 190.6 to $258.9 \mathrm{mv}$. Maximum ORP value of $258.9 \mathrm{mv}$ has been recorded at a STW (49.09) located at Jhilim union and minimum ORP value of $49.20 \mathrm{mv}$ (sample ID-RCW-12) has been recorded at a STW $(24.39 \mathrm{~m})$ located at Char Anupnagar Union. The temperatures of the groundwater samples are uniform showing a narrow range of 25.7 to $27.6^{\circ} \mathrm{C}$. However, the maximum temperature of $27.6^{\circ} \mathrm{C}$ has been recorded at a STW $(51.52 \mathrm{~m})$ located at Jhilim union and a minimum value of $25.7^{\circ} \mathrm{C}$ has been recorded at a STW $(29.26 \mathrm{~m})$ located at the same Union of the investigated area. Recorded turbidity of groundwater samples ranges from 0.16 to 7.61 NTU which are within the DoE standard. Maximum turbidity value of 7.61 NTU has been recorded at a STW $(16.19 \mathrm{~m})$ located at Gobratola union and minimum value of 0.16 has been recorded at a STW well $(24.39 \mathrm{~m})$ at Char Anupnagar Union.

\section{Major ions concentration:-}

Sodium concentration in the shallow groundwater samples of the investigated area rages from 31.68 to $52.8 \mathrm{mg} / \mathrm{l}$. All the 14 ground water samples exhibit Na concentration within the DoE standard. Maximum concentration of 52.8 $\mathrm{mg} / \mathrm{l}$ has been recorded in a STW $(13.72 \mathrm{~m}$ ) located at Maharajpur Union and minimum concentration of $31.68 \mathrm{mg} / \mathrm{l}$ has been recorded in a STW $(71.34 \mathrm{~m})$ located at Debinagar Union. Potassium concentration in shallow groundwater samples of the investigated area ranges from 1.25 to $9 \mathrm{mg} / \mathrm{l}$. All the 14 ground water samples are within the DoE standard. Maximum concentration of $9 \mathrm{mg} / \mathrm{l}$ has been recorded in a STW $(13.72 \mathrm{~m})$ located at Maharajpur Union and minimum concentration of $1.25 \mathrm{mg} / \mathrm{l}$ has been recorded in a STW $(36.59 \mathrm{~m})$ located at Jhilim Union. Calcium concentration in shallow groundwater samples of the investigated area ranges from 36 to $142 \mathrm{mg} / \mathrm{l}$. Out of 14 groundwater samples three samples are within DoE standard. Other 11 samples exceed the standard. Maximum concentration of $142 \mathrm{mg} / \mathrm{l}$ has been recorded in a STW $(33.54 \mathrm{~m})$ located at Baragharia Union and the minimum concentration of $36 \mathrm{mg} / \mathrm{l}$ has been recorded in a STW $(36.59 \mathrm{~m})$ located at Jhilim Union of the investigated area. Magnesium concentration in shallow groundwater samples of the investigated area ranges from 2.46 to $54.21 \mathrm{mg} / \mathrm{l}$. Out of 14 ground water samples, only 1 sample exceeds the DoE standard. Other 9 samples are below the DoE standard and four samples are within the DoE standard. Maximum concentration of $54.2 \mathrm{mg} / \mathrm{l}$ has been recorded in a STW (13.72m) located at Maharajpur Union and minimum concentration of $2.46 \mathrm{mg} / \mathrm{l}$ has been recorded in a STW $(33.54 \mathrm{~m})$ located at Baragharia Union. Bicarbonate concentration in shallow groundwater samples of the investigated area ranges from 250 to $636 \mathrm{mg} / \mathrm{l}$. Out of 14 ground water samples Only 1 sample is within the WHO limit. Other 13 samples exceed the WHO limit and so are not safe for drinking purpose. Maximum concentration of $636 \mathrm{mg} / \mathrm{l}$ has been recorded in a STW $(21.34 \mathrm{~m})$ located at Debinagar Union and minimum concentration of 250 $\mathrm{mg} / \mathrm{l}$ has been recorded in a STW $(36.59 \mathrm{~m})$ located at Jhilim Union of the Chapainawabganj Sadar upazila. $\mathrm{Cl}^{-}$ concentration in shallow groundwater samples of the investigated area ranges from 6.719 to $63.062 \mathrm{mg} / \mathrm{l}$. All the 14 ground water samples are within the DoE standard. Maximum concentration of $63.062 \mathrm{mg} / \mathrm{l}$ has been recorded in a STW $(13.72 \mathrm{~m})$ located at Maharajpur Union and minimum concentration of $6.719 \mathrm{mg} / \mathrm{l}$ has been recorded in a STW $(21.34 \mathrm{~m})$ located at Sunderpur Union. Sulfate concentration in shallow groundwater samples of the 
investigated area ranges from 0.652 to $23.05 \mathrm{mg} / \mathrm{l}$. All the 14 ground water samples are within DoE standard. Maximum concentration of $23.05 \mathrm{mg} / \mathrm{l}$ has been recorded in a STW $(13.72 \mathrm{~m})$ located at Maharajpur Union and minimum concentration of $6.719 \mathrm{mg} / 1$ has been recorded in a STW $(16.17 \mathrm{~m})$ located at Gobratola Union. Nitrate concentration in shallow groundwater samples of the investigated area ranges from 0.753 to $31.297 \mathrm{mg} / \mathrm{l}$. Out of 14 ground water samples only one sample exceeds the DoE standard. Other 13 samples are within the DoE standard. Maximum concentration of $31.297 \mathrm{mg} / \mathrm{l}$ has been recorded in a STW $(16.17 \mathrm{~m})$ located at Gobratola Union and minimum concentration of $0.753 \mathrm{mg} / \mathrm{l}$ has been recorded in a STW $(24.39 \mathrm{~m})$ located at Char Anupnagar Union of the investigated area.

\section{Minor Ions and Trace Elements:-}

Phosphate concentrations in the ground water samples are very low in the investigated area. Only four samples show $\mathrm{PO}_{4}{ }^{-}$concentration of $2.076 \mathrm{mg} / \mathrm{l}, 4.656 \mathrm{mg} / \mathrm{l}, 19.443 \mathrm{mg} / \mathrm{l}$, and $67.092 \mathrm{mg} / \mathrm{l}$ respectively. Other 10 samples have no $\mathrm{PO}_{4}{ }^{-}$content. Only two samples exceed the DoE standard. Maximum concentration of $67.092 \mathrm{mg} / \mathrm{l}$ has been recorded in a STW $(21.34 \mathrm{~m})$ located at Debinagar Union and minimum concentration of $2.076 \mathrm{mg} / \mathrm{l}$ has been recorded in a STW $(13.72 \mathrm{~m})$ located at Maharajpur Union. Nitrite concentration in shallow groundwater samples of the investigated area ranges from 0.753 to $31.297 \mathrm{mg} / \mathrm{l}$. Out of 14 ground water samples only one sample exceeds the DoE standard. Other 13 samples are within the DoE standard. Maximum concentration of $31.297 \mathrm{mg} / \mathrm{l}$ has been recorded in a STW $(21.34 \mathrm{~m})$ located at Sunderpur Union and minimum concentration of $0.753 \mathrm{mg} / \mathrm{l}$ has been recorded in a STW $(29.27 \mathrm{~m})$ located at Baliadanga Union of the investigated area. $\mathrm{F}^{-}$concentration in shallow groundwater samples of the investigated area ranges from 4.86 to $7.19 \mathrm{mg} / \mathrm{l}$. All the 14 groundwater samples exceed the DoE standard. Maximum concentration of $7.19 \mathrm{mg} / \mathrm{l}$ has been recorded from a STW $(29.26 \mathrm{~m})$ located at Baliadanga Union and minimum concentration of $4.86 \mathrm{mg} / \mathrm{l}$ has been recorded from a IW $(51.51 \mathrm{~m})$ located at Jhilim Union. Iron concentration ranges from 4.86 to $7.19 \mathrm{mg} / \mathrm{l}$. All the 14 ground water samples exceed the DoE standard. Maximum concentration of $7.19 \mathrm{mg} / \mathrm{l}$ has been recorded in a STW $(29.27 \mathrm{~m})$ located at Baliadanga Union and minimum concentration of $4.86 \mathrm{mg} / \mathrm{l}$ has been recorded in a STW $(51.52 \mathrm{~m})$ located at Jhilim Union. Manganese concentration in shallow groundwater samples of the investigated area ranges from 0.02 to $0.89 \mathrm{mg} / \mathrm{l}$. Out of 14 groundwater samples only 3 samples are within the DoE standard. Other 11 samples exceed the limit. Maximum concentration of $0.89 \mathrm{mg} / \mathrm{l}$ has been recorded in a STW $(21.34 \mathrm{~m})$ located at Sunderpur Union and minimum concentration of $0.02 \mathrm{mg} / \mathrm{l}$ has been recorded in a STW $(36.59 \mathrm{~m})$ located at Jhilim Union. Zinc concentration in shallow groundwater samples of the investigated area ranges from 0.023 to $0.339 \mathrm{mg} / \mathrm{l}$. All the 14 groundwater samples are within the DoE standard. Maximum concentration of $0.339 \mathrm{mg} / \mathrm{l}$ has been recorded in a STW (49.09 m) located at Jhilim Union and minimum concentration of $0.023 \mathrm{mg} / \mathrm{l}$ has been recorded in a STW $(51.52 \mathrm{~m})$ also at Jhilim Union. Copper concentration in shallow groundwater samples of the investigated area ranges from 0.001 to $0.013 \mathrm{mg} / \mathrm{l}$. DoE standard for $\mathrm{Cu}^{2+}$ is $1 \mathrm{mg} / \mathrm{l}$. All the 14 ground water samples are within the DoE standard. Maximum concentration $0.013 \mathrm{mg} / \mathrm{l}$ has been recorded in a STW $(36.59 \mathrm{~m})$ located at Jhilim Union and minimum concentration of $0.001 \mathrm{mg} / \mathrm{l}$ has been recorded in a STW $(13.72 \mathrm{~m})$ located at Maharajpur Union. Lead concentration in shallow groundwater samples of the investigated area ranges from 0.09 to $0.13 \mathrm{mg} / \mathrm{l}$. DoE standard for $\mathrm{pb}^{2+}$ is $0.05 \mathrm{mg} / \mathrm{l}$. Out of 14 ground water samples, 5 samples exceed the DoE standard. Other 9 samples have concentrations value below the detection limit. Maximum concentration of $0.013 \mathrm{mg} / \mathrm{l}$ has been recorded in an IW (49.09 m) located at Jhilim Union and minimum concentration of $0.09 \mathrm{mg} / \mathrm{l}$ has been recorded in two STW (13.72 m and $24.39 \mathrm{~m}$ ) located at Maharajpur and Anupnagar Union of the investigated area. Nickel concentration in shallow groundwater samples of the investigated area ranges from 0.022 to $0.0 .04 \mathrm{mg} / \mathrm{l}$. All the 14 ground water samples are within the DoE standard. Maximum concentration of $0.04 \mathrm{mg} / \mathrm{l}$ has been recorded in a STW $(13.72 \mathrm{~m})$ located at Maharajpur Union and minimum concentration of $0.022 \mathrm{mg} / \mathrm{l}$ has been recorded in a STW $(16.16 \mathrm{~m})$ located at Gobratola Union. Cobalt concentration in shallow groundwater of the investigated area ranges from 0.013 to 0.024 $\mathrm{mg} / \mathrm{l}$. Maximum concentration of $0.024 \mathrm{mg} / \mathrm{l}$ has been recorded in a STW $(29.27 \mathrm{~m})$ located at Jhilim Union and minimum concentration of $0.013 \mathrm{mg} / \mathrm{l}$ has been recorded in a STW $(16.16 \mathrm{~m})$ located at Gobratola Union of the investigated area. In the Barind Tract area no arsenic has been detected in the groundwater samples because of the limitation of the HACH EZ arsenic Test Strip to detect below the value of $5 \mathrm{ppb}$. In the flood plain area arsenic has been recorded within the range of 0.015 to $0.1 \mathrm{mg} / \mathrm{l}$. As concentration detected in the laboratory ranges from 0.001 to $0.11 \mathrm{mg} / \mathrm{l}$. Out of 14 ground water samples only 3 samples exceed the DoE standard. The other 11 samples are within the DoE standard. Maximum concentration of $0.11 \mathrm{mg} / \mathrm{l}$ has been recorded in a STW $(16.16 \mathrm{~m})$ located at Gobratala Union and minimum concentration of $0.001 \mathrm{mg} / \mathrm{lo}$ has been recorded in a TARA Hand Pump (29.27 m) located at Jhilim Union of the investigated area. 


\section{Minerals of subsurface sediments and their possible impact on Groundwater:-}

In order to identify mineral composition of sediments of aquifers and aquitards of the study area, a total number of 51 representative samples have been collected from 14 boreholes. Out of 51 representative samples 18 are clay samples and 33 are sand samples. From Barind Tract Area Clay samples have been collected from $4.57 \mathrm{~m}$ to $32 \mathrm{~m}$ depth and in Flood Plain areas from $1.53 \mathrm{~m}$ to $33.53 \mathrm{~m}$ depth. On the other hand, the depth range of sand samples in the Barind Tract varies from $25.91 \mathrm{~m}$ to $43.58 \mathrm{~m}$ whereas in the Flood Plain areas it varies from $3.05 \mathrm{~m}$ to $46.63 \mathrm{~m}$. The quality of groundwater reflects the mineralogical composition of the rocks with which the water has been in contact. As water moves slowly through the subsurface its composition gradually changes, reflecting the increasing saturation of some ions or the end products of various rock-water interactions. In the Petrology and Mineralogy Lab of GSB, the clay samples have been studied through X-RD and sand samples have been studied under polarizing microscope. In total 11 clay minerals both from Barind Tract and Flood Plain areas have been identified through X$\mathrm{RD}$ analysis (Panalytical XPERT- PRO, Generator Setting 30mA 40kV, Cu Tube). The identified major clay minerals are Illite, Chlorite, Clinochlore, Kaolinite and Montmorillonite. The minor clay minerals are Halloysite, Phlogopite, Lepidolite, Zeolite (hydrous sodium calcium aluminum silicates), Muscovite and Biotite. Besides, 18 minerals have been identified from sand samples under polarizing microscope (Eclipse LV100 POL). Some opaque minerals have also been found in the grain slide but it could not be identified. The identified major minerals are Quartz, Feldspar and Mica which constituted $80 \%$ of the total minerals. The minor minerals are Augite, Hornblende, Kyanite, Actinolite, Toumaline, Zircon, Garnet, Monazite, Sillimanite, Rutile, Anatase, Calcite and Opaque minerals.

It may be mentioned that groundwater type is acidic to neutral ( $\mathrm{pH}$ value ranges from 6.31 to 7.12 ) and environment is oxidizing (ORP value ranges from 19.6 to $258.9 \mathrm{mv}$ ) in the Barind Tract areas, on the other hand groundwater type is similar in nature like Barind Tract and reducing environment (ORP value ranges from -0.6 to $-190 \mathrm{mv}$ ) exists in the Flood Plain areas respectively. In neutral condition $\mathrm{Na}^{+}, \mathrm{K}^{+}, \mathrm{Ca}^{2^{+}}, \mathrm{Mg}^{2+}, \mathrm{Cl}^{-}, \mathrm{SO}_{4}{ }^{2^{-}}$and $\mathrm{HCO}_{3}{ }^{-}$are common in groundwater.

\section{Geophysical Survey:-}

Geophysical Survey has been conducted to identify physical characteristics of the subsurface materials. Resistivity Survey has been carried out to delineate subsurface layering and underground water bearing formations. Vertical Electrical Sounding (VES) technique has been adopted in this regard. To correlate the geophysical logs with the borehole logs geophysical well loggings have been conducted into all the boreholes.

\section{Resistivity Survey:-}

Resistivity survey has long been used for groundwater exploration and the method is proved to be very successful for the development of groundwater resource (Bugg \& Lloyed, 1976; Serres, 1969; Urish \& Frohlich, 1990; Woobaidullah et al, 1996). To fulfill the objective of this programme Vertical Electrical Sounding (VES) employing schlumberger configuration have been conducted at 16 different locations of the study area to follow resistivity variation with depth. Each location is treated as separate VES number such as VES 1, VES 2 etc. Out of 16 VES, 9 VES (VES 1, VES 6, VES 7, VES 8, VES 9, VES 10, VES 11, VES 13, VES 14 with $100 \mathrm{~m}$ spreads, VES 12 with $400 \mathrm{~m}$ spread and VES 16 with $500 \mathrm{~m}$ spread) have been conducted at the flood plain area and the rest 5 VES (VES 2, VES 3, VES 4, VES 5, VES 11 with $100 \mathrm{~m}$ spreads and VES 15 with $500 \mathrm{~m}$ ) spreads have been conducted at Barind Tract area. 16 VES field curves have been generated from 16 traverses.

\section{Interpretation and findings of Vertical Electrical Soundings (VES):-}

The bore log data of the study area shows that the sediments are clay, silt, clayey pebbles and grabbles and sands of different sizes. Resistivity response against these sediments is not uniform and depends on the type and nature of the sediments and the type of water within the pore space. Clay shows high resistivity variations depending on the dry and wet conditions. Dry and hard clay shows high resistivity value but the water bearing clay shows very low resistivity value. On the other hand, the conductivity of sands varies mostly due to the presence of pore water. Sands containing fresh water show higher resistivity than sands containing saline water. Clay with silt or clayey pebbles sometimes shows resistivity within the range of fresh water bearing fine sand. Interpreted geophysical data (Table 1) shows that the northeastern part of the investigated area which is Barind Tract is broadly a three-layer section. The upper layer shows the resistivity variation due to the nature and wetness of the top soil. The resistivity of this layer varies from $10.59 \Omega \mathrm{m}$ (VES 11) to $31.69 \Omega \mathrm{m}$ (VES 02). The thickness of this layer varies from $0.57 \mathrm{~m}$ (VES 03) to $1.47 \mathrm{~m}$ (VES 04). Where the surface soil/landfill is hard and dry and composed of clay with occasionally silt, the resistivity varies from $18.06 \Omega \mathrm{m}$ (VES 05) to $31.69 \Omega \mathrm{m}$ (VES 02). And where the surface soil is clayey with silt and 
contains moisture the resistivity varies from $10.59 \Omega \mathrm{m}$ (VES 11) to $12.07 \Omega \mathrm{m}$ (VES 15). The second layer is a continuous layer and the resistivity ranges from $6.36 \Omega \mathrm{m}$ (VES 03) to $13.57 \Omega \mathrm{m}$ (VES 02). Thickness of this layer varies from $13.52 \mathrm{~m}$ (VES 02) to $27 \mathrm{~m}$ (VES 05). Low resistivity values indicate that this layer consists mainly of silty clay (Barind Clay) which is wet. The maximum thickness of this layer occurs in the northeastern part of the study area i.e. Hussain Danga and Jhilim Union. The thickness of this clay layer gradually decreases towards south of the study area. The third layer shows maximum resistivity of $47.95 \Omega \mathrm{m}$ (VES 11) and minimum resistivity of $19.48 \Omega \mathrm{m}$ (VES 05). The thickness of this layer could not be determined due to the limited spread of current electrodes. The reisitivity variations indicate that this layer consists mostly of fine to medium grained sand that contains water. Results of interpretations from the VES are shown in the Table.

Table:-Results of Vertical Electrical Sounding in the surveyed area.

\begin{tabular}{|c|c|c|c|c|c|c|c|}
\hline $\begin{array}{l}\text { VES } \\
\text { No. }\end{array}$ & $\begin{array}{c}\text { Resistivity } \\
(\Omega \mathrm{m})\end{array}$ & $\begin{array}{l}\text { Thickness } \\
\text { (m) }\end{array}$ & Lithilogy & $\begin{array}{l}\text { VES } \\
\text { No. }\end{array}$ & $\begin{array}{c}\text { Resistivity } \\
(\Omega \mathrm{m})\end{array}$ & $\begin{array}{l}\text { Thickness. } \\
\text { (m) }\end{array}$ & Lithology \\
\hline \multirow{3}{*}{ VES 01} & 62.96 & 4.12 & Top Soil & \multirow{3}{*}{ VES 02} & 31.69 & 1.30 & Top Soil/Landfill \\
\hline & 49.51 & 17.89 & C. Sand & & 13.57 & 13.52 & Barind Clay \\
\hline & 22.94 & $\sim 27$ & F. Sand & & 19.73 & $\sim 45$ & F. Sand \\
\hline \multirow[b]{3}{*}{ VES 03} & 19.99 & 0.57 & Top Soil & \multirow[b]{3}{*}{ VES 04} & 20.41 & 1.47 & Top Soil \\
\hline & 6.36 & 24.67 & Barind Clay & & 7.65 & 14.90 & Barind Clay \\
\hline & 20.64 & $\sim 29$ & F. Sand & & 34.60 & $\sim 33$ & M. Sand \\
\hline \multirow{4}{*}{ VES 05} & 18.06 & 1.28 & Silty Clay & \multirow{4}{*}{ VES 06} & 72.76 & 0.59 & Top Soil/Landfill \\
\hline & 9.26 & 3.43 & Barind Clay & & 907.84 & 1.18 & C. Sand \\
\hline & 19.48 & 23.57 & F. Sand & & 137.04 & 42.74 & C. Sand \\
\hline & 30.36 & Infinity & M. Sand & & 16.89 & $\sim 5$ & F. Sand \\
\hline \multirow{3}{*}{ VES 07} & 171.90 & 3.79 & Top Soil & \multirow{4}{*}{ VES 08} & 13.05 & 0.83 & Top Soil/Landfill \\
\hline & 36.058 & 2.08 & M. Sand & & 2572.9 & 2.01 & C. Sand \\
\hline & 110.66 & $\sim 39$ & C. Sand & & 15.15 & 5.52 & F. Sand \\
\hline \multirow{3}{*}{ VES 09} & 341.65 & 1.78 & Top Soil & & 1853.9 & $\sim 41$ & C. Sand \\
\hline & 130.59 & 49.04 & C. Sand & \multirow{3}{*}{ VES 10} & 687.55 & 0.44 & Top Soil \\
\hline & 20.99 & $\sim 4$ & F. Sand & & 48.12 & 10.66 & C.Sand \\
\hline \multirow{3}{*}{ VES 11} & 10.59 & 1.42 & $\begin{array}{l}\text { Top } \\
\text { Soil/Landfill }\end{array}$ & & 31.38 & $\sim 38$ & M. Sand \\
\hline & 7.33 & 16.73 & Barind Clay & \multirow{4}{*}{ VES 12} & 407.46 & 0.94 & Top Soil \\
\hline & 47.95 & $\sim 31$ & C. Sand & & 21.94 & 11.59 & F. Sand \\
\hline \multirow{4}{*}{ VES 13} & 83.54 & 0.51 & Top Soil & & 42.17 & 14.65 & C. Sand \\
\hline & 845.00 & 3.65 & C. Sand & & 32.71 & $\sim 132$ & M. Sand \\
\hline & 123.93 & 28.09 & C. Sand & \multirow{3}{*}{ VES 14} & 130.14 & 0.76 & Top Soil \\
\hline & 36.46 & $\sim 12$ & M. Sand & & 680.00 & 1.70 & C. Sand \\
\hline \multirow{5}{*}{ VES 15} & 12.07 & 0.98 & Silty Clay & & 44.61 & $\sim 42$ & C. Sand \\
\hline & 6.37 & 18.58 & Barind Clay & \multirow{4}{*}{ VES 16} & 51.88 & 5.30 & Top Soil \\
\hline & 31.07 & 106.28 & M. Sand & & 347.83 & 5.89 & C. Sand \\
\hline & 16.74 & $\sim 74$ & F. Sand & & 34.29 & 112.95 & M. Sand \\
\hline & & & & & 10.92 & $\sim 75$ & Clay \\
\hline
\end{tabular}

*C, F \& M denote respectively as Coarse, Fine and Medium.

Floodplain area in the southwestern part is broadly of two-layer section. The upper layer which extends all over the area shows the resistivity variation due to the nature and wetness of the top soil. The resistivity of this layer varies from $13.05 \Omega \mathrm{m}$ (VES 08) to $687.55 \Omega \mathrm{m}$ (VES 10). The thickness of this layer varies from $0.44 \mathrm{~m}$ (VES 10) to 5.30 $\mathrm{m}$ (VES 16). The 2nd layer shows the maximum resistivity of $2572.9 \Omega \mathrm{m}$ (VES 08 ) and the minimum resistivity of $21.94 \Omega \mathrm{m}$ (VES 12). The thickness of this layer could not be determined due to the limited spreading of current electrodes. The resistivity variations indicate that this layer consists mostly of fine to medium grained sand and contains water. There are some geo-electric interfaces in the 2 nd layer which may be due to the variation in compaction and lithology of sand. There is only one location in the flood plain area with a three-layer section (VES 16). 


\section{Borehole Geophysical logging:-}

In present geophysical borehole logging only Conductivity and Natural Gamma logs have been conducted because of the limitation of channels in the supplied instrument. The geophysical data acquisitions have been performed by a specially designed slim-hole composite logger for plastic cased hole.

\section{Interpretations and findings of borehole geophysical logging:-}

Different lithological units have been constructed from geophysical logs of the study area and compared with the bore logs to decipher the true picture of subsurface lithology. These lithologies are silty clay, sand and micaceous sand. In Barind Tract region thick silty clay (Barind Clay?) layer having average thickness of $25 \mathrm{~m}$ has been identified from interpreted logs on the basis of high Gamma response (>200CPS-220 CPS) and relatively high conductivity (>100 mS/m-140 mS/m) values. A thin sand layer (24 to $28 \mathrm{~m}$ ) within the silty clay layer (Barind Clay?) has been identified at Sisatola, Jhilim on the basis of comparatively low value of gamma and conductivity. Below the silty clay a sand layer (Dupi Tila sand?) is identified that shows frequent fluctuation of gamma value $(<100 \mathrm{CPS})$ with relatively low conductivity value $(<40 \mathrm{mS} / \mathrm{m})$. In Flood plain area a topmost silty clay layer having average thickness of $5 \mathrm{~m}$ has been identified from interpreted logs. This layer has been identified on the basis of high Gamma response (>100CPS-120 CPS) and relatively high conductivity $(>50 \mathrm{mS} / \mathrm{m}-100 \mathrm{mS} / \mathrm{m})$ values. Below the silty clay layer, a sand layer has been identified that shows frequent fluctuation of gamma value $(<100 \mathrm{CPS})$ with relatively low conductivity value ( $<30 \mathrm{mS} / \mathrm{m}$. Three thin silty clay layers ( 4 to $8 \mathrm{~m}, 22$ to $24 \mathrm{~m}$ and 29 to $31 \mathrm{~m}$ ) have been identified within the sand layer at Debinagar logs on the basis of relatively high Gamma as well as Conductivity values. Besides, some high gamma responses may indicate the presence of huge amount of mica or organic materials in this layer. The base of the sand layer is not identified due to limitation of drilling depth.

\section{Conclusion And Recommendations:-}

From Bangladesh perspective, the significance of groundwater is enormous. It is not only used as a source of drinking water but also used in agricultural, industrial sectors and in recent days also used for recreation purposes.

In Chapainawabganj Sadar Upazila, mainly two water bearing zones have been identified, one of which is situated in Alluvial Formation of Holocene age in Recent Flood Plane areas and the other one is in Dupi Tila Formation beneath the Barind Clay Residuum Formation of Plio-Pliestocene age in Barind Tract areas.

The results of chemical analysis of groundwater samples revealed that all the elements are not relevant to human health but some harmful trace elements like manganese $(\mathrm{Mn})$, nickel $(\mathrm{Ni})$, arsenic $(\mathrm{As})$, lead $(\mathrm{Pb})$ and cadmium $(\mathrm{Cd})$ etc. are also detected. The link between excesses or deficiencies of particular trace element and health are likely more noticeable in rural areas because of much greater dependence on groundwater.

Mineralogical analysis indicates that minerals of the water bearing zones predominately consists of silicate minerals like quartz, feldspar, mica, hornblende, augite, chlorite, kaolinite, montmorillonite etc. These minerals are contributing different elements in groundwater under different geo-chemical environment.

From the practical point of view, it is most important that a pilot investigation of water quality should be carried out before large scale groundwater extraction for various purposes.

Multidisciplinary studies involving geologists, geophysicists, chemist and mineralogists are also essential to assess the natural and anthropogenic impacts on groundwater. Hydro-geochemical database is similarly important to reduce the risk of mortality and morbidity. 


\section{References:-}

1. Acharyya SK, Chakraborty P, Lahiri S, Raymahashay BC, Guha S, Bhowmik A.Nature. 1999 Oct 7;401(6753):545; discussion 546-7.

2. BBS, 2012. Statistical Yearbook of Bangladesh, Bangladesh Bureau of Statistics (www.bbs.gov.bd).

3. BGS-DPHE. 2001. Arsenic Contamination of Groundwater in Bangladesh; British Geological Survey and Department of Public Health Engineering; Government of Bangladesh, final report; Vol-2. p.48

4. Berg, M., Stengel, C., Trang, P.T.K., Viet, P.H., Sampson, M., Leng, M., et al., 2007. Magnitude of arsenic pollution in the Mekong and Red River Deltas - Cambodia and Vietnam. Sci. Total Environ. 372, 413-425.

5. Bhattacharya, P., Chatterjee, D. \& Jacks, G. (1997) Occurrence of arsenic contaminated groundwater in alluvial aquifers from Delta Plains, Eastern India: Options for safe drinking water supply. Int. Jour. Water Res. Dev., 13(1):7992.

6. Bhattacharya, P., Frisbie, S.H., Smith, E., Naidu, R., Jacks, G., Sarkar, B., 2002a. Arsenic in the Environment: A Global Perspective. In: Sarkar, B. (Ed.), Handbook of Heavy Metals in the Environment. Marcell Dekker Inc., New York, pp. 145-215.

7. Bhattacharya, P., Ahmed, K.M., Hasan, M.A., Broms, S., Fogelström, J., Jacks, G., Sracek, O., von Brömssen, M., Routh, J., 2006. Mobility of arsenic in groundwater in a part of Brahmanbaria district, NE Bangladesh. In: Naidu, R., Smith, E., Owens, G., Bhattacharya, P., Nadebaum, P. (Eds.), Managing Arsenic in the Environment: from Soils to Human Health. CSIRO Publishing, Collingwood, Australia, pp. 95-115.

8. Bugg, S.F. and J.W. Lloyd.1976. A study of fresh water lens configuration in the Cayman Island using resistivity method. Q. J. Eng. Geol. pp. 9291-9302.

9. Department of Environment (DoE). 1997. Environmental Quality Standards for Bangladesh.

10. Garcia, Maria \& Bundschuh, Jochen. (2006). Arsenic in groundwater of Latin America-A challenge of 21 st century. Geol. Soc. Am. Abstracts and Programs. 38.

11. Goriar, R, Chakraborty, K. \& Pyne, R. (1984) Chronic arsenic poisoning from tubewell water. Journal of the Indian Medical Association, 82: 34-35.

12. Guha Mazumder, D.N., Chakraborty, A.K., Ghose, A., Gupta, J.D., Chakraborty, D.P., Dey, S.B. \& Chattopadhyay, N. (1988) Chronic arsenic toxicity from drinking tubewell water in rural West Bengal. Bulletin of the World Health Organization, 66(4): 499-506.

13. Khan, M.R. and Mominullah, M. 1980. Stratigraphy of Bangladesh. Petroleum and Mineral Resources of Bangladesh, Ministry of Petroleum and Mineral Resources, Govt. of Bangladesh, pp. 35-40.

14. Khan, A. A., and Rahman, T. 1992. An Analysis of the Gravity fields and Tectonic evolution of the north western part of Bangladesh,Tectono-physics. Vol 206; pp. 351-364.

15. Khan, A.A. And Sattar, G.S. 1994. Over exploration of ground water and its environmental impact in the Barind, Bangladesh. Regional workshop on environmental aspect of ground water development, Vol-IV; pp. 37-44

16. Khondoker, R. A. 1987. Origin of elevated Barind-Madhupur areas, Bengal basin: Result of neotectonic activity. Bang. Jour. Geol., v.6, pp. 1-9.

17. Mandal, B and Suzuki, K. (2002) Arsenic round the World: A Review. Talanta, 58, 201-235. http://dx.doi.org/10.1016/S0039-9140(02)00268-0

18. Monsur, H. M. 1995. An introduction to Quaternary Geology of Bangladesh, City Press \& Publications. Dhaka,70p.

19. Mukherjee, A., Fryar, A.E., 2008. Deeper groundwater chemistry and geochemical modeling of the arsenic affected western Bengal Basin, West Bengal, India. Applied Geochemistry. 23 (4), 863-894.

20. Nickson, R.T., J.M. Mcarthur, B. Shrestha, T.O. KyawMyint and D. Lowry. 2005. Arsenic and other drinking water quality issues, Muzaffargarh District, Pakistan. Applied Geochemistry 20(1): 55-68.

21. O'Shea, B., Jankowski, J. \& Sammut, J. (2007) The sources of naturally occurring arsenic in coastal sand aquifer of eastern Australia, Sci. Tot. Env, 379; 151-166.

22. Raghunath, H.M., 1990. Ground Water. Wiley Eastern Limited. 4835/24 Ansari Road, Daryaganj, New Delhi 110002. p. 266.

23. Serres, Y. F., 1969. Resistivity prospecting in a United Nation groundwater project of western Argentina, Geophysical Prospecting. 17: 449-467.

24. Urish, D.W. and Frohlich, R.K., 1990. Surface electrical resistivity in coastal groundwater exploration. Geoexploration, 26: 267-289.

25. Woobaidullah, A.S.M., M. Rahman and R. Amdt.1996. Electrical survey for groundwater exploration in the coastal belt of Sathkhira, north-west Bangladesh. Jour.Geologiche Bundes Anstalt, Austria. Pp. 127-137

26. Welch, A.H., Watkins, S.A., Helsel, D.R., and Focazio, M.F., 2000, Arsenic in groundwater resources of the United States: U.S. Geological Survey Fact Sheet 063-00, 4p. 